\title{
CHROMOSOME NUMBERS IN CHILEAN SPECIES OF LUZURIAGA RUIZ ET PAV. (LUZURIAGACEAE)
}

\section{NUMEROS CROMOSOMICOS EN ESPECIES CHILENAS DE LUZURIAGA RUIZ ET PAV. (LUZURIAGACEAE)}

\author{
Pedro Jara-Seguel \& Cristina A. Zúñiga
}

Escuela de Ciencias Biológicas y Químicas, Facultad de Recursos Naturales, Universidad Católica de Temuco, Casilla 15-D, Temuco-Chile. pjara@uct.cl

\begin{abstract}
Mitotic chromosome counts for Luzuriaga radicans Ruiz et Pav. and L. polyphylla (Hook) J.F. Macbr. from Chile, reported here for the first time, are the same as those reported for L. parviflora (Hook) Kunth in New Zealand and $L$. marginata (Gaertner) Benth. on Falkland Islands $(2 \mathrm{n}=2 \mathrm{x}=20)$. These results indicate a constancy of chromosome number in the genus Luzuriaga.
\end{abstract}

Luzuriaga Ruiz et Pav. (Luzuriagaceae) is a small genus, with three species in the southern cone of South America $\left(36^{\circ}-50^{\circ} \mathrm{S}\right)[$ L. radicans Ruiz et Pav. L. polyphylla (Hook.) J.F. Macbr. and L. marginata (Banks et Sol. ex Gaertn.) Benth.], and a single species in New Zealand, L. parviflora (Hook.) Kunth (Fineran 1964; Moore \& Edgar 1970; Arroyo \& Leuenberger 1988a, 1988b). This genus is a clear example of the floristic links between distant land masses of the southern hemisphere (Arroyo \& Leuenberger 1988b). Historically, the taxonomic status of the genus Luzuriaga has been controversial, with four different classifications having been proposed at family level (Arroyo \& Leuenberger 1988a). However, its adscription to the family Luzuriagaceae has now found general acceptance (ArroyoLeuenberger 2001, APG II 2003).

Chromosome numbers of Luzuriaga spp. have been reported previously from New Zealand, and from the Falkland Islands, but not for Chilean species of the genus (Rodríguez \& Marticorena 1987). The New Zealand species L. parviflora (Beuzenberg \& Hair 1963) and L. marginata from the Falkland Islands (Moore 1968) were both found to have a diploid complement $2 \mathrm{n}=2 \mathrm{x}=20$.

To complement the existing cytogenetic data on the genus Luzuriaga, chromosome counts were carried out in L. radicans and L. polyphylla from southern Chile. Specimens of one accession of each species were obtained from naturally growing populations (Table I). The voucher specimens were deposited in the herbarium (UCT) of the School of Biological and Chemical Sciences of the Universidad Católica de Temuco. In the laboratory, plants were kept with their rhizomes submerged in water subject to constant aeration, to favor active growth of adventitious roots. After seven days, $5 \mathrm{~mm}$-long root tips were excised from the rhizomes. Chromosomes were obtained and stained according to the protocol described by Jara-Seguel \& Zúñiga (2004).

Luzuriaga radicans y L. polyphylla both show a basic chromosome number $\mathrm{x}=10$. Pairs of homologous chromosomes were identified during metaphase, enabling to deduce that both species have a diploid chromosome complement of $2 \mathrm{n}=2 \mathrm{x}=20$. In both species, a pair of acrocentric chromosomes were observed with secondary constriction and a satellite on the short arm (Fig. 1a-b).

Our results on chromosome counts in $L$. radicans y L. polyphylla match the basic number $\mathrm{x}=10$ and the diploid level $2 \mathrm{n}=2 \mathrm{x}=20$ previously described for L. parviflora (Beuzenberg \& Hair 1963) and L. marginata (Moore 1968). Additionally, the secondary constriction and the satellite located on the short arm in acrocentric chromosomes, are a common character in L. radicans, L. polyphylla 
y L. parviflora. On the basis of this cytogenetic evidence and despite the geographic insulation between South American and New Zealand taxa, the genus Luzuriaga may be considered chromosomally stable with a constancy of the chromosome number and in the chromosome location of the satellites. Similarly, in the closely-related genus Alstroemeria L. (Alstroemeriaceae) (see Rudall et al. 2000), with nearly 50 species recognized, a constancy of the chromosome number $2 \mathrm{n}=2 \mathrm{x}=16$ has also been described in all 27 species which have been cytogenetically examined to date (Buitendijk \& Ramanna 1996; Sanso \& Hunziker 1998; Sanso 2002; Jara-Seguel et al. 2004). In this genus, due to its interspecific uniformity in karyotype asymmetry, mechanisms of karyotype orthoselection were proposed as probable evolutionary trends (Sanso 2002).

TABLE I. Collection sites of Luzuriaga spp.

\begin{tabular}{|c|c|c|}
\hline Species & Phrts & Collectian sites \\
\hline Iuzwiag rodis ws & 6 & 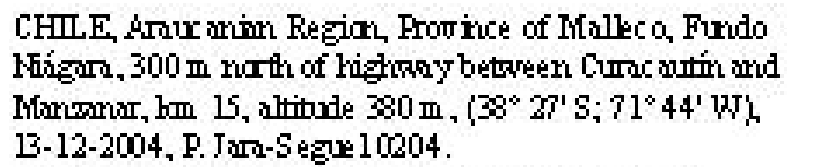 \\
\hline Lusuringa yolys hylih & 4 & 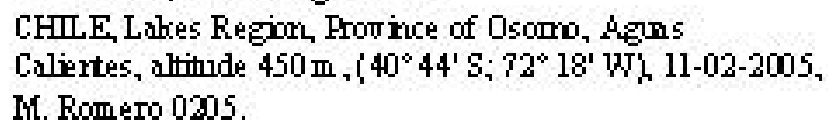 \\
\hline
\end{tabular}
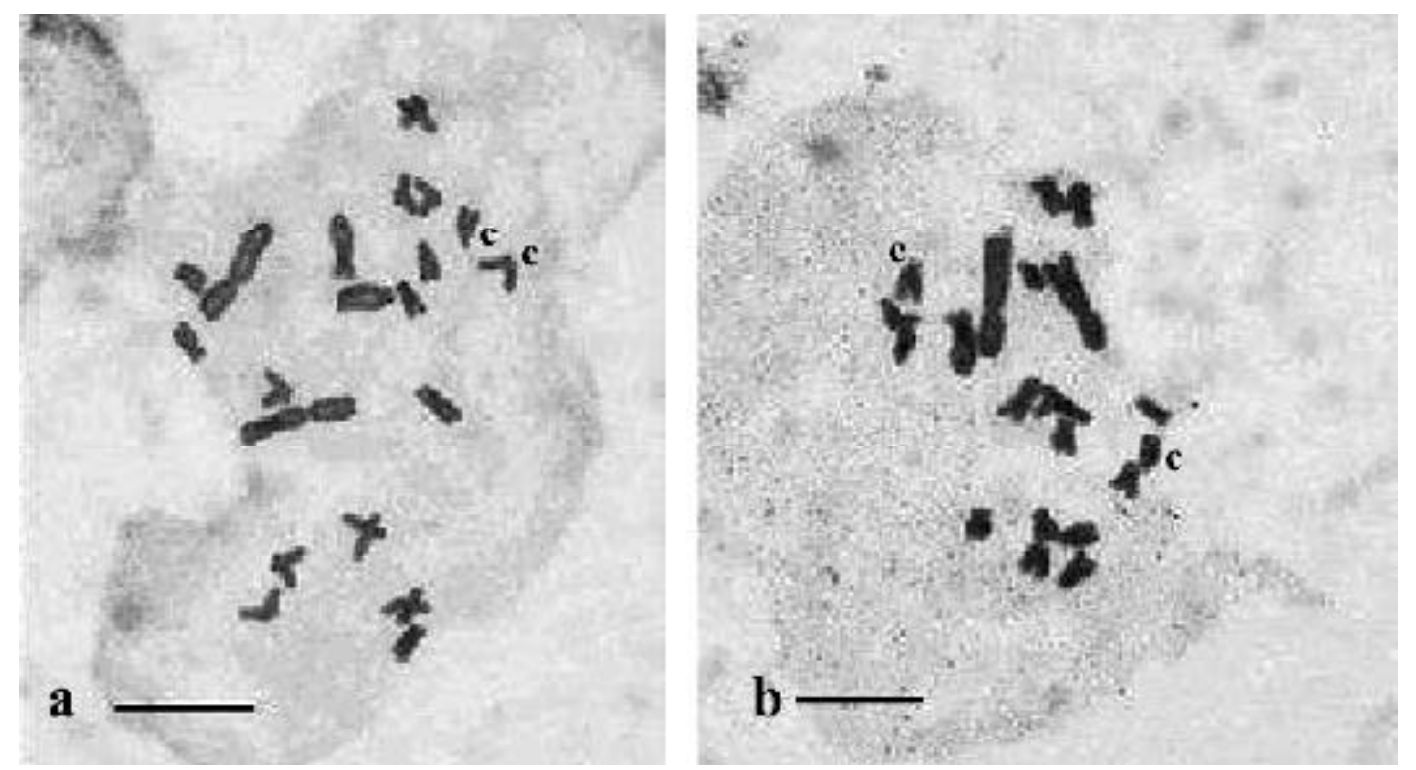

FIGURE 1. Mitotic metaphases $2 \mathrm{n}=2 \mathrm{x}=20$ of (a) Luzuriaga radicans and (b) L. polyphylla. "c" identifies chromosomes with secondary constriction and satellite on the short arm. Scale bar represents $10 \mu \mathrm{m}$. 
Studies on comparative karyology of Luzuriaga (e.g. chromosome morphology, C-banding pattern, genomic in situ hybridization, meiotic chromosome pairing) may help elucidate trends in karyotype evolution, degrees of genomic differentiation, genetic flow between species, and the cases of genetic self-incompatibility described previously in L. radicans (Riveros et al. 1996) and L. polyphylla (Arroyo \& Humaña 1999). Furthermore, the cytogenetic data may complement the framework of biosystematics research in the family Luzuriagaceae, whose phylogenetic relationships with other families within the order Liliales have been outlined only on the basis of morphological characters and nucleotide sequences of nuclear, plastid and mitochondrial DNA (Rudall et al. 2000; Soltis et al. 2000; Vinnersten \& Bremer 2001; APG II 2003; Davis et al. 2004; Janssen \& Bremer 2004).

\section{ACKNOWLEDGMENTS}

We are grateful to Mario Romero for his help with fieldwork, and to Enrique Hauenstein for reading the manuscript. Thanks to Dr. C. Lusk for his suggestions. Financed by DGIUCT Project 2005-4-02.

\section{BIBLIOGRAPHY}

APG II. 2003. An update of the Angiosperm Phylogeny Group classification for the orders and families of flowering plants. Botanical Journal of the Linnean Society 141: 399-436.

Arroyo, S. \& B. Leuenberger. 1988a. Leaf morphology and taxonomic history of Luzuriaga (Philesiaceae). Willdenowia 17: 159-172.

Arroyo, S. \& B. LeUENBerger. 1988b. A note on Luzuriaga marginata (Philesiaceae) from Patagonia. Herbertia 44: 17-21.

Arroyo-leuenberger, S. 2001. Flora Fanerogámica Argentina: Philesiaceae, Asteliaceae y Luzuriagaceae. Pro-Flora CONICET 72: 1-7.

Arroyo, M. \& A. Humaña. 1999. Breeding systems of two endemic rainforest species in southern Chile: Amoryrtus meli (Phil.) Legr. et Kaus. (Myrtaceae) and Luzuriaga polyphylla (Hook.) Macbr. (Philesiaceae). Gayana Botanica 56: 31-37.

Beuzenberg, E. \& B. Hair. 1963. Contributions to a chromosome atlas of the New Zealand flora - 5, miscellaneous families. New Zealand Journal of Botany 1: 53-67.
Buitendisk, J. \& M. Ramanna. 1996. Giemsa C-banded karyotypes of eigth species of Alstroemeria $\mathrm{L}$. and some of their hybrids. Annals of Botany 78: 449 457.

Davis, J., D. Stevenson, G. Petersen, O. Seberg,L.C Aampbell, J. Freudenstein, D. Goldman, C. Hardy, F. Ichelangeli, M. Simmons, C. Specht, F. VergaraSilva \& M. Gandolfo. 2004. A Phylogeny of the Monocots, as Inferred from $r b c L$ and atpA sequence variation, and a comparison of methods for calculating Jackknife and bootstrap values. Systematic Botany 29: 467-510.

Fineran, B. 1964. Some plant records from Port Pegasus, Stewart Island. New Zealand Journal of Botany 2: 380-384.

J ANSSEN, T. \& K. BREMER. 2004. The age of major monocot groups inferred from $800+r b c L$ sequences. Botanical Journal of the Linnean Society 146: 385-398.

J ARA-SEguel P. \& C. ZúÑIGA. 2004. El cariotipo de Lapageria rosea Ruiz et Pav. (Liliales: Philesia-ceae). Gayana Botanica 61: 76-78.

Jara-Seguel, P., C. Palma-Rojas \& E. Von Brand. 2004. Karyotype and C-bands in the annual Inca Lily Alstroemeria graminea Phil. Belgian Journal of Botany 137: 199-204.

Moore, D. 1968. The vascular flora of the Falkland Islands. In: British Antarctic Survey, Scientific Report 60. London. $201 \mathrm{pp}$.

M oore, L. \& E. Edgar. 1970. Flora of New Zealand. Vol. II. Wellington, Govermment Printer. 354 pp.

Riveros, M.,A. Humaña \& M. Arroyo. 1996. Sistemas de reproducción en especies del bosque valdiviano $\left(40^{\circ}\right.$ Latitud Sur). Phyton (Buenos Aires) 58: 167-176.

Rodríguez, R. \& C. Marticorena. 1987. Las especies del género Luzuriaga R. et P. Gayana Botanica 44: 315.

Rudall, P., W. Hong, J. Conran, C. Furness, G. Kite \& M. Chase. 2000. Consider the lilies: Systematics of Liliales. In: Monocots: systematics and evolution (eds. K. Wilson \& D. Morrison), Pp. 347-359. Collingwood: CSIRO. 728 pp.

SANSO, M. \& J. HunZIKER. 1998. Karyological studies in Alstroemeria and Bomarea (Alstroemeriaceae). Hereditas 129: 67-74.

SAnso, M. 2002. Chromosome studies in Andean Taxa of Alstroemeria (Alstroemeriaceae). Botanical Journal of the Linnean Society 138: 451-459.

Soltis, D., P. Soltis, M. Chase, M. Mort, D. Albach, M. Zanis, V. Savolainen, W. Hahn, S. Ноot, M. Fay, M. Axtell, S. Wensen, L. Prince, W. Kress, K. NIXON \& J. FARRIS. 2000. Angiosperm phylogeny inferred from $18 \mathrm{~S}$ rDNA, $r b c L$, and $a t p B$ sequences. Botanical Journal of the Linnean Society 133: 381461.

VinNersten, A. \& K. BRemer. 2001. Age and biogeography of major clades in Liliales. American Journal of Botany 88: 1695-1703. 